\title{
Family Relationships of a Crack Cocaine-Using Pregnant Women in a Brazilian Northeastern City
}

July Grassiely de Oliveira Branco', Juliana Guimarães e Silva², Aline Veras Morais Brilhante ${ }^{3}$, Antônio Dean Barbosa Marques ${ }^{4}$, Raimunda Magalhães da Silva ${ }^{5}$, Maria Vieira de Lima Saintrain ${ }^{6}$, Francisca Lucélia Ribeiro de Farias ${ }^{8}$, Ana Maria Fontenele Catrib ${ }^{9}$, Aline de Souza Pereira ${ }^{10}$, Luana Feitosa Mourão11, Christina Cesar Praça Brasil'12, Luiza Jane Eyre de Souza Vieira ${ }^{13}$

\section{Abstract}

Background: This article aims to describe family relationships of a crack cocaine-using pregnant woman through a genogram.

Methods: A qualitative case study was carried out, in which semistructured interviews were applied with the selected pregnant woman, three relatives and one health professional. The interviews were analysed using thematic content analysis and the results favored the construction of a genogram.

Results: The results show a nuclear family formed by slum dwellers, with too close emotional relationships among some of the members; at the same time, the existence of fragile relationships are also highlighted, but the abuse of crack cocaine was not enough to change them, Drug use changed her trajectory to move through the health system.

Conclusion: There is a need to raise awareness among health professionals about the care and monitoring of psychoactive substance users, in order to overcome barriers to access and improve the understanding about their family relations. José Manuel Peixoto Caldas 7 ,

1 Master in Public Health from University of Fortaleza, UNIFOR. Performing PhD in Public Health from the University of Fortaleza, UNIFOR.

$2 \mathrm{PhD}$ in Public Health from ENSP/FIOCRUZ. Performing Post Doctorate in Public Health in University of Fortaleza.

$3 \mathrm{PhD}$ in Public Health from UECE/UFC/ UNIFOR. *

4 Master in Public Health from University of Fortaleza, UNIFOR. Performing PhD in Clinical Care Nursing and Health from State University of Ceará.

$5 \mathrm{PhD}$ in Nursing from the University of São Paulo, USP. Post Doctorate from University of Campinas...

$6 \mathrm{PhD}$ in Odontology and Public Health from University of Pernambuco. Post Doctorate from the University de Campinas, UNICAMP.

$7 \mathrm{PhD}$ in Sociology from University of Barcelona. Investigator of Center for Health Technology and Services Research. Professor University of Porto

$8 \mathrm{PhD}$ in Nursing from EERP-USP RP. Performing Post Doctorate from the Federal University of Rio Grande do Sul, UFRS. *

$9 \mathrm{PhD}$ in Education from the Federal University of Bahia, UFBA/ISC. Post Doctorate from University of Campinas. .

$10 \mathrm{PhD}$ in Public Health from UECE/UFC/ UNIFOR. .

11 Graduated in Nursing Federal University of Piaui.

$12 \mathrm{PhD}$ in Public Health from UECE/UFC/ UNIFOR. .

$13 \mathrm{PhD}$ in Nursing from Federal University of Ceará. Performing Post Doctorate from the Federal University of Bahia, UFBA/ISC. ${ }^{*}$ *: Professor at the University of Fortaleza

\section{Contact information:}

July Grassiely de Oliveira Branco. 


\section{Introduction}

Although it is still underestimated and not visible by the population, the use of psychoactive substances by women has been increasing [1]. Research has reported that the recognition of drug addiction among women is still not acclaimed [2]. Authors like Soares, et al. claim that the use of psychoactive substances by women is not a recent phenomenon. In this context, a new problem is becoming increasingly common: the use of psychoactive substances during pregnancy [3].

A study on the use of psychoactive substances during pregnancy shows that in the United States, in 2010, $4.4 \%$ of pregnant women, used drugs [4]. In Brazil, Rocha et al., a research with 1.447 pregnant women living in a capital of the brazilian northeast region, estimated a prevalence of $1.45 \%$ for the use of illicit drugs, $22.32 \%$ for alcohol and $4.22 \%$ for tobacco [5].

This reality requires an increase in qualified professionals capable of recognizing and identifying the problem, taking into account the risk for injuries related to substance use in the mother-child dyad, the risks inherent to the body's vulnerable condition and the maternal-fetal exchanges and those arising from the women's behavior, when using the sexual act as a bargaining chip to obtain drugs even during pregnancy [6].

The use of psychoactive substances affects family dynamics beyond individual factors [6]. Noteworthy, interpersonal behaviors depend, among other factors, on the actions of other interaction partners, i.e., they include complex emotional, relational and communicational aspects of interdependence in family's relationships [7]. Given the complexity [8] of these relationships, it can be said that analyzing the interrelationships between the family and a pregnant drug user is of utmost importance for understanding the phenomenon.

The term family can be conceptualized as asocially constituted arrangement made up of rules, practices and values that has included many different structures in contemporary society [9]. In ge- neral, it is associated with the social role of care, identity formation and social protection provided to their members [10]. However, to consider the family group as a single entity with pre-determined roles is quite risky given the diversity of family model sand the multiplicity of interactive and behavioral patterns and symbolic systems that the term comprises [7]. Examples of the non-fixity of the concept of family are the changes in family configurations triggered by women's achievements [11].

Therefore, research involving families must take into consideration the complexity of the relationships within this social group, especially when there is the need to move forward in relation to sociodemographic data, which, although important, cannot explain the complexity of this social group [7, 12].

Thus, this article aims to describe family relationships of a crack cocaine-using pregnant woman through a genogram.

\section{Methods}

This article is part of a master's degree thesis that investigated the trajectory of a crack cocaine-using pregnant woman and her search for care within the health system.

This study is the result of a Masters dissertation that investigated the trajectory of a crack-using pregnant women in health services, evaluating the use of soft technologies. The research is inserted in a larger project that made the assessment of women's health and the interface with comprehensiveness, technology and health promotion.

It is a qualitative case study [13] that aimed to map, describe and analyze the context, relationships and perceptions regarding the situation, phenomenon or episode at issue [14].

The entry into the research field started through contact made with professionals of the six health districts and with the Women's Health Coordination, which is responsible for the Stork Network in the city of Fortaleza-Ceará, providing opportunities for access to health managers and employees 
of the Regional Executive Secretariat V (Secretaria Executiva Regional - SER V). The case addressed in the present study was selected after contacting the professionals, considering the following inclusion criteria: being pregnant, be more than 18 years old, be user of the public health system for the prenatal and psychoactive substance follow-ups. According to these criteria, the user was chosen taking into account the complexity of the situation and the particularities of the territory, respecting the risk areas.

The city of Fortaleza is divided in six administrative Regional Executive Secretariat. The Region $V$ of the city, composed by 570,000 inhabitants, distributed in 18 neighborhoods, was chosen for presenting the highest social vulnerability in the city of Fortaleza. It is the most populous and also the poorest region in the city, with an average household income of 3.07 minimum wages. It also has the largest youth population of the city- $44 \%$ of the population aged up to 20 years - and it is the second with the highest illiteracy rate (17.83\%) [15].

In addition to the selected pregnant woman, three family members and health workers involved in the trajectory of her health care. The interviews were conducted using a semi-structured questionnaire and recorded with permission of the respondents. For the pregnant woman, the interview was conducted through the following questions: (i) tell us about your story (family, pregnancy and drug use); (ii) how is your relationship with the members of your family?; and (iii) talk about the health care you receive or received. For family members, the following questions were used: (i) how is your relationship with the pregnant?; and (ii) you know which kinds of care she is receiving or received related to the pregnancy and to the use of drugs?. For the professionals, it was asked about their relation with the user. All the respondents were encouraged to narrate feely about the case.

The information obtained was grouped with progress notes, referral forms, information from pre- natal care booklets and field notes taken in every meeting with the participants.

Interview data were subjected to thematic content analysis, which occurred in three steps: a) data ordering; b) data classification, accomplished by a deep and careful reading of each interview and the completion of the notes contained in the diary, for the preparation of the analysis categories; c) final analysis, by linking the corpus of research and the theoretical framework [14] and the information obtained was used for the construction of a genogram. From this analysis emerged the following categories: (a) family relationships; (B) approach to the abused drug; and (c) therapeutic course.

A genogram is a graphical representation of a person's family relationship that has recently become widespread in qualitative research focused on family $[16,7]$. It is widely used in public health and can be applied in the characterization and registration of family groups in the Family Health Strategy (FHS) with the aim to promote community health and disease prevention as well as facilitate the visualization and understanding of the disease process and the main diseases that affect family members [17]. More recently, the genogram has been used as a scientific tool in qualitative research involving family groups [7].

Fictitious names were given to the participants and to the health services involved in this research to ensure the anonymity and privacy. This study was authorized by the Ethics Committee under the approval No.055/2010.

\section{Results}

\section{Relação Familiar}

The family context reproduced here depicts the experience of a lower-class family who lives in a slum and is marked by extreme poverty. The study reveals very close affective relationships between some of its members and, also, highlights the existence of 
fragile relationships, which weren't worsened due to substance abuse.

Anastásia - according to her mother - is the eldest of four children and was born on October 10, 1986. She is a protestant working-class black woman who is a mother of three children, works in the food industry and is a user of psychoactive substance since 1998. In 2012, she started using crack cocaine and she informed that she decided to be abstinent in November 2014

Her father (John) is alive and lived in the same household as Anastasia until she was 14 (in the year of 2000). Her mother said that she divorced John because he used to tell her to look for other men and physically assaulted her in front of their children. In addition, he also abused alcohol and kept extramarital affairs, which led her to avoid contact after divorce.

John is 57 years old and works as a night watchman. He has episodes of depression and abuses alcohol. After the divorce, which did not happen by legal means, he jumped into a new relationship with Renata. Both live in Fortaleza, in a brick house, with a 15 year-old boy who is the child from Renata's previous relationship.

Alice - Anastasia's mother - is 49 years old and suffers from asthma and hypertension, a condition that is treated with the continued use of medication. She works as a babysitter. She is completely illiterate but knows the alphabet. She stands out for helping in solving problems of people who live in her community - retirement and hospitalization issues. She considers herself as "successful" person.

From Alice and John union were born three children: Anastasia (28 years old), Carla (26 years old) and Homero (25 years old).

Anastasia studied until the first year of high school. She is a diabetic crack user and has three children (a 13-year-old boy from her first marriage, and the other two - six and three years old - from the second marriage). At the age of 13, she ran away from the house where she lived with her mother to live with Kelton (30 years old), who works as a truck loader. Fromthis union, Bruno was born in 2002. In 2008, this relationship came to an end. Her son remained living with his father and Anastasia returned to her mother's house. That was when she met Abraham, her current husband, and moved away with him to live in his relatives' home.

According to the Community Health Agent (CHA) who is responsible for assisting the area in which the user's home is inserted, 25 people - 12 adults and 13 children - lived in the house where Anastasia lived in 2009. None of the adults worked, and everyone lived the way they could. The reason for the change in this scenario is unknown by the CHA, but Anastasia talks openly about it: she said that, in 2011, the older people who lived in the house left because the younger people used to drink a lot and make use of psychoactive substances. The house was, then, divided. Anastasia and her family got a room in the back; which became bigger and is now the home where they live, after some reforms carried out over the years.

Thus, in 2015, she lived with her husband and two children in the aforementioned house. The house had four rooms, running water and sewage treatment system, but the outside was not painted. It is located in a neighborhood on the outskirts of the city of Fortaleza, in the Administrative Region with the lowest average personal income.

Regarding work, Anastasia reports she works as a warehouse assistant in a food company. During this study period (January 2015), she was licensed by the National Social Security Institute (Instituto Nacional do Seguro Social - INSS) due to hospitalization for detoxification of psychoactive substance (crack cocaine) and because the medications used by her also caused sleepiness.

Anastasia has sporadic contact with her father, they just see each other once in a while. Alice says that, in times of discussion between the father and daughter, Anastasia recalls the occasions when he physically assaulted her mother and does not forgive him for this. 
Carla, in turn, has no morbidities and addictions up to now. She studied until the $5^{\text {th }}$ grade and lives with her husband Thaddeus - a 30-year-old joiner - and two children (an 11 year old girl and a 7 year-old boy) in a brick house in a community near her mother's house, in the southeast part of Fortaleza city.

Homero is 25 years old, single and has no children. He works as a sales promoter in a mediumsized company and is studying the fifth semester of law.. He has been living in his mother's seven-room brick house for six years (2009) along with his stepfather and an aunt (his father's sister). He lived with his maternal grandparents until the age of 19 in a city 136 km away from Fortaleza.

After separation, Alice met Mauricio, a 40-yearold informal worker with whom she had another daughter in 1999 - Catherine, 16 years old now. Alice shares her home with Mauricio, her son Homero and her ex-sister-in-law Antoinette (57 years old).

When asked about her relationship with family members, Anastasia tells that she gets along well with Alice, Mauricio, Carla and Catherine. Anastasia says that her relationship with Homero is troubled because he keeps saying that their mother gives more attention to her "drug addicted daughter" than to him, who works and studies. According to the mother, Homero is jealous and makes her responsible for not helping him in his ventures (the construction of an Internet café in a room in the house).

Catherine studied until the fifth grade of elementary school. She does not work and has no addictions and morbidities. She has a one-year old daughter and is two months pregnant. She lives with her daughter and her husband, Jonas, six houses away from her mother's house. Jonas is 18 years old, works as a salesman in the local market and earns one minimum wage.

Figure 1 shows the organizational representation of Anastasia's family members and the existing family relationships between them through a graphic resource.

Figure 1: Anastacia's Family genogram.

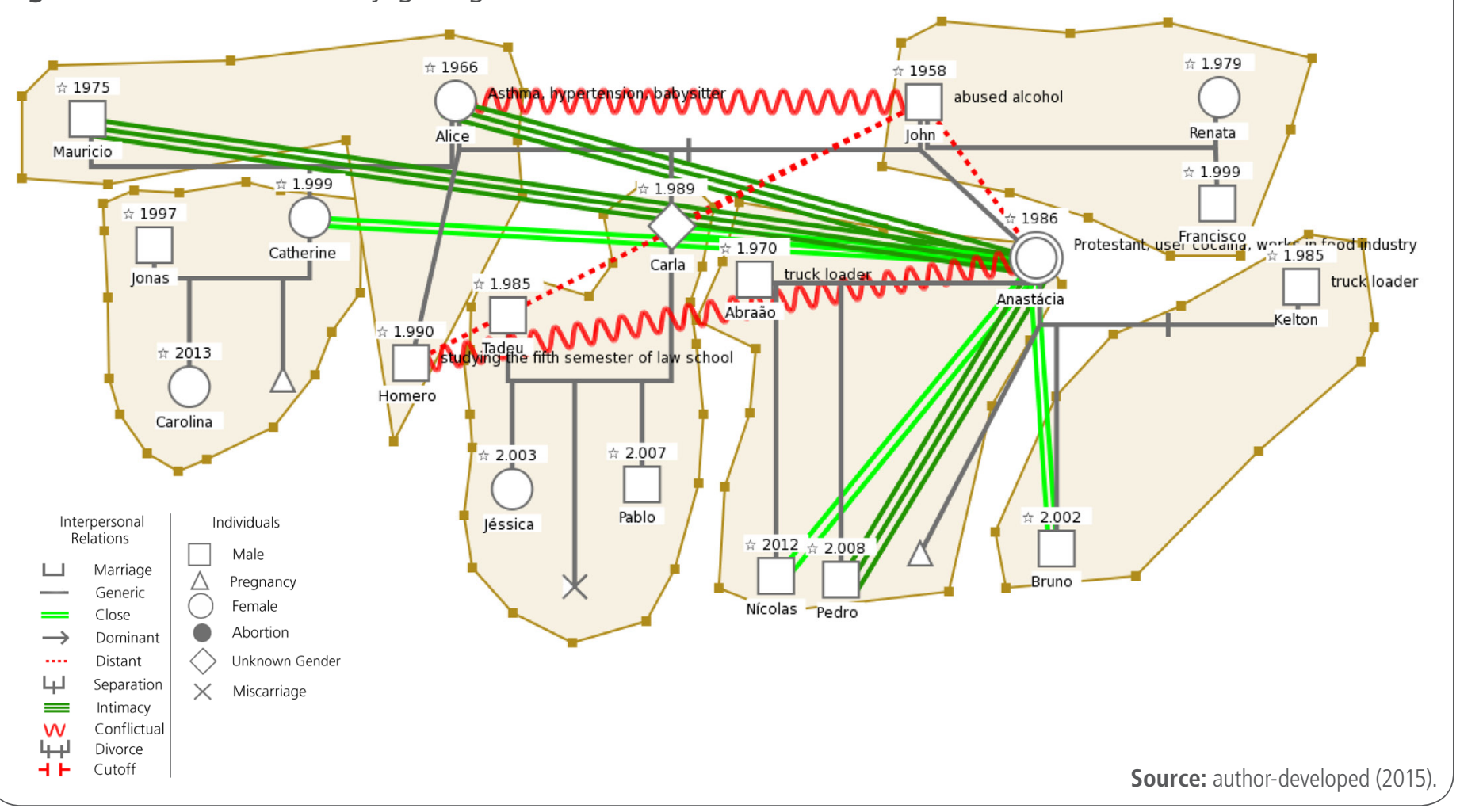




\section{Approach to the abused drug}

The use of crack cocaine is not recent in her life. Anastasia says that, about two or three years ago (2011 or 2012), she started the abusive use of drugs, but she doesn't Know exactaly when she migrated from cocaine to crack cocaine. She explains that the use of substances in general began as a "joke" - when she hang out with her friends and her sister, they drunk alcohol, which later led her to cocaine, culminating in the use of crack cocaine.

According to her, the first time she experienced the crack cocaine was during the carnival of 2011; she told she was home alone when the sister in law arrived and offered her. She used once, twice, until it went to almost daily use. Anastasia says that the use of psychoactive substances began when she was 12 (1998), with cannabis sativa, popularly known as marijuana.

The moment the user met the psychoactive substance is unknown to her mother, despite her sister had warned her constantly about this possibility and the comments made by some neighbors who used to see Anastácia near the "smoke mouth."

Her sister in law said she had made use of psychoactive substance a lot of times in her company. She said that she has control over this use, but Anastacia doesn't. The use occurs at parties, in friends' houses, according to the reports of her sister in law.

Anastacia confirmed she had made use of crack cocaine along with her sister in law and that she prefers to use it at home; but that she has consumed twice in other people's houses. She also told she had never smoked "on the street". Her sister said that she twice witnessed drug use scenes in the user's house.

Anastasia says that when she doesn't have money to purchase the substance she doesn't buy it - noting that she doesn't give away any of her belongs for any value for this purpose anymore, act she had already performed numerous times.
About crack cocaine use itself, Anastacia says that "the feeling is very good, but then comes the depression and regret. There comes my subconscious. I do not want, but I'm doing." And complements with the following words:[...]

[...] I can not explain how was the feeling. It seems that you leave yourself. You do something without sense of what you're doing. If you have ten thousand Reais, you spend it all, you spend little by little until you have not a penny, and then you think: My God! Did I spent it all? Then you see you did it unintentionally, but you did.

She said that despite not assuming the use of substances to her husband, initially; he suspected something was wrong, due to her behavior motivated by continuous crack cocaine use. The reason that made her assume to her housband the use of drugs was realizing the harmful effects of addiction. The husband did not accept the situation, which led to numerous conflicts, some even threatening to leave her and take the children if she persisted in use. She continues stating that, despite the threats, she made use of crack cocaine in November 2014. Her husband noticed the use and started a new discussion, which made her realize the consequences of her actions and seek treatment.

Anastacia explains that when she assumed the abuse of the substance to her husband, she did the same before her mother, to whom asked for help to care for her children, which made possible her hospitalization for treatment.

Alice, when asked about the involvement of Anastasia's father in this issue of drug use, she confesses that "he is not involved in this, he doesn't talk about this."

After treatment in February 2015, the fearful mother says 
[...] [...] the only thing that I always wonder is if she is no longer using [drugs] and she tells me that, thank God, she has left and is no longer using. But it's like this: I'm always ear standing, because mothers don't trust this. I pray to God that she does not come back, because if it were the first time, all right, but it is not. She always falls on the problem again.

Six months after the treatment, Alice confides: "I think she is ashamed, I think she left this drug, now she's building all over again. She is motivated to clean the house and everything. I'm even impressed, but nothing for God is hard, I think she has changed...

In May 2015, after six months of abstinence and in the seventh month of pregnancy, Anastasia had a relapse, getting to use 10 crack cocaine rocks. Her husband stepped in and brought her inside their house, threatening to leave her again. The purchase of the crack cocaine was made by the user, whose husband said that "traffickers know she is pregnant, but they sell the drug without restrictions because they want to make money and are not concerned with anyone who wants to die."

\section{Therapeutic Path}

In November 2014, Anastasia was admitted in a general hospital, in Fortaleza-Ceará, where she spent 12 days for detoxification, being prescribed medications for the "abandonment of addiction." During the hospital stay, despite Anastácia have reported changes in the intensity of her menses and amenorrhea in the previous month, there was no investigation of a possible pregnancy. The changes in the menstrual cycle were attributed to adverse reactions caused by the treatment.

After the discharge from the detox treatment, in December 2014, she presented bloating, abdominal pain and nausea, looking for the emergency service of a maternity hospital for two times, with an interval of ten days. Although she has been seen by two different doctors, both prescribed painkillers, releasing her in sequence. On the third visit to the hospital, in January 2015, the doctor who attended her investigated the possibility of pregnancy, being "discovered" a singleton pregnancy, at 14 weeks. Anastacia was then driven to start prenatal care.

Due to the health team's lack of knowledge about the effects of substance abuse and the kinds of drugs used for the treatment of the abuse, the user was referred to the high-risk prenatal care.

On February 11, she was attended by the obstetrician in prenatal high risk clinic. Consultations at high risk ambulatory were always performed with the same doctor, who although very attentive, showed up "without further knowledge of the harmful effects of drugs on pregnancy", which again advised Anastácia to seek care with a psychiatrist.

All appointments with the psychiatrist were performed in the emergency department, due to the inavailability of ambulatorial consultations. Two appointments were held until the end of pregnancy.

\section{Discussion}

The structural arrangement shown refers to the recreation of a family. According to Caniço et al., it consists in a new conjugal union where there may be children from previous relationships of either party. Its marital relationship is considered traditional and it is structured upon the roles of the genders, i.e., each member has functions towards family and society that have already been established [18].

Anastasia's nuclear family is made of people of humble origins with low level of education, which can be explained by social exclusion, which helps to deepen the family's economic hardship and triggers the need for early entry into the labor market. Moreover, teenage pregnancies seem to be repeated within the family. 
According to Kurz, the patriarchal society legitimates man's power to determine the social roles, defines what can be tolerated and punishes any deviations from the recommended functions. It is evident, therefore, that the patriarchal family model gives man authority over the family, establishing his power over his wife and children, who submit to his orders and can be punished by him - an action that is socially acceptable [19].

In the context of this family, remaining at school is no longer a viable choice as their survival depends on working. According to Madeira [20], corroborated by the European Commission [21], early school leaving and early entry into the labor market are motivated by economic and social issues that increase the need to postpone this project. Nevertheless, the need to delay formal education appears as one of the conditions for the precarious entry into the labor market, reducing expectations of better living conditions in the future.

Another reason for school dropout is teen pregnancy. A study conducted by the Brazilian Institute of Geography and Statistics (Instituto Brasileiro de Geografia e Estatísticas - IBGE), in 2013, revealed that $88.1 \%$ of women aged between 15 and 17 years old who had no children went to school at that time. On the other hand, only $28.5 \%$ of women who had one child or more than one went to school, and $68.7 \%$ of them were not enrolled in school and did not finish high school - the appropriate grade level they should be attending [22].

A study by Borja and Martins [23], conducted with a group of former students, also showed that one of the factors contributing to school leaving is teenage pregnancy. Additionally, in the aforementioned study, teenage women's partners appear as barriers as they do not agree with the fact that their partners have to stay away from home for a longer period of time. Noteworthy, income transfer programs that stimulate permanence at school date from 2011 and can minimize this problem.
With regard to social class, the family described in the present study can be classified as a class $D$ and E family - or lower class. Families within this social class have at least one employed member in the household receiving approximately one minimum wage per month. Their homes are generally located in high-poverty areas.

In Brazil, a country marked by social inequalities where many families like Anastasia's - slum-dwelling poor black woman - live in precarious conditions, there are, in addition to the several hardships and lack of opportunities, problems related to gender and race.

Race issues in Brazil, particularly the ones relating to the Black population, are a historical problem that began with the arrival of these people in the country in subhuman conditions, they were transported and marketed as objects, enslaved and deprived of their liberty, desires and rights. After they were set free, Black people were not inserted in society as being equal to other individuals. In fact, they could only perform jobs that were unwanted by Whites. Brazil's social debt with these people refers to the lack of access to better living and working conditions and results in the perpetuation of their anomie in the social environment $[24,25,26]$.

As for family experiences and factors that can reinforce the use of psychoactive substances, the family is marked by episodes of intrafamily violence followed by the parents' home-leaving after separation, which makes them lose contact with their children. Facts like this refer to the family function, which, instead of being present as a protection against the use of narcotic substances, acts as a trigger for their abuse, being fueled by domestic violence, rows, abandonment and a bad environment [27, 28].

The role of the father, who - according to the patriarchal model idealized - should provide their children with protection, becomes a negative example for children, which is reinforced when he abuses alcohol or assaults his wife. 
Given this problem, it is believed that the attitudes and positions taken by family members responsible for taking care of the children - father, mother or guardian - are likely to trigger the abuse of licit or illicit drugs by other members [29, 30, 31]. However, the social vulnerability of this family associated with the fragility of family ties seem to increase daily difficulties and weaken their coping strategies, which indicates the need to understand the complexity of their contexts and the relationships they build.

With regard to Anastasia, it is clear that the experimentation of psychoactive substances at the age of 12 and "running away" from home at the age of 13 may have motivated by the violent environment. The childhood and early adolescence experiences have reverberated throughout her experience of adulthood, not only with regard to the repetition of her mother's behavior concerning the years spent at school, but also the use of psychoactive substances.

Gender violence affects women not only in adulthood, but also in childhood and adolescence. This violence is established by power relationships $[32,33]$.

It is, according to Zuma et al. [34] , p. 149,

[...] any act that results in physical or emotional harm perpetrated with the abuse of power of one person over another within a relationship built upon inequality and asymmetry between genders. It can occur in intimate relationships between partners, between co-workers, and in relational spaces.

Corroborating this concept, violence manifests itself in the action of domination and affirmation of power that is present in the family dynamics with impact on other family members who experience it [35]. In situations in which victims are women, children and adolescents, the violence suffered may produce negative repercussions in adulthood. In the case of this population, the violence suffered refers to the violation of human rights, which characte- rizes a serious public health problem $[36,37,38]$.

In the family context, the use of psychoactive substances can cause harms to its members due to the changes they generate in the household dynamics, financial expenses, and the increased dispensation of care $[39,40]$. Thus, the family is a recipient of the problems generated by substance abuse, suffering and being intimidated by fear, violence, and haunted by the risk of having other members getting involved with the drug due to the lack of knowledge about how to proceed in such situation [41].

Thus, qualified institutions and professionals should assist not only the user but also the family whose ties have been weakened by the harmful effects of the substances used by family members in order to change the user's habits through family support and confidence [41].

\section{Conclusions}

The case of Anastasia, addressed in this research, points out that the abuse of the substance has not been enough to change family relationships. Initia$\| y$, this use occurred in relatives' and friends' companies, in parties, as a way to have fun. The usage evolution led Anastácia to the search for care at a hospital for 12 days, which resulted in a period of abstinence with subsequent relapse at the end of the pregnancy. On the other hand, substance use, regardless of its usage pattern, changed her trajectory to move through the health care system. The main barriers were: difficulties in pregnancy identification, displacement for high risk monitoring without proper assessment of the case, lack of psychiatric monitoring and lack of obstetrician knowledge about the effects of drug use during pregnancy.

Based of this results, it is still early and somewhat deterministic to blame the use of psychoactive substances only on the user's family given that little affective families are also present in the history of 
many regular users. Additionally, violence is not only present within the family environment, but also in their daily lives due to the social context in which they are inserted.

The repetition of the familiar pattern brought by these women - for instance, teenage pregnancy, economic hardship, poor education, and early entry into the labor market - demonstrates a vicious cycle where the basic needs for survival prevails over the desire to acquire formal education.

The case presented herein has also a history of parents who have been victims of violence and abandonment in childhood, situations that affect their lives as adults in terms of the emotional aspect and difficulties of family life. Domestic violence between the parents, with attacks made against the children (physical, psychological, sexual), can also affect the subject throughout life in society.

Associated with this scenario, we point the social vulnerability linked to violence as one of the pillars for the abuse of psychoactive substances, given that such reality is constituted by favorable conditions for use such as: influence of friends, lack of family orientation, lack of education and the presence of violent environment.

In this scenario, there is a need to raise awareness among health professionals about the care and monitoring of psychoactive substance users, in order to overcome barriers to access. It is recommended encouraging the participation of users as protagonists in the process of care and the effectiveness of the link between obstetric and psychiatric assistances.

Assuming that the use of psychoactive substances is a public health problem, it is the role of the State to ensure not only the treatment of drug-abusing individuals, but also the family, through public policies that recognize both as part of the same family problem.

\section{References}

1. Gouin K., Murphy K., Shah PS. (2011). Effects of cocaine use during pregnancy on low birthweight and preterm birth: systematic review and metaanalyses. Am J Obstet Gynecol. 2011 Apr; 204(4):1-12. Available in: http://www.sciencedirect. com/science/article/pii/S0002937810022672

2. Oliveira JF, Paiva MS, Valente CML. A interferência do contexto assistencial na visibilidade do consumo de drogas por mulheres. Rev La Am Enfermagem. 2007 mar-apr; 15(2):247-252. Available in: http://www.scielo.br/pdf/rlae/v15n2/pt v15n2a09.pdf

3. Soares LCO, Ruzzi-Pereira A, Pereira PE, Cavalcanti A, Andrade VS. Papéis ocupacionais de mulheres que fazem uso abusivo de substâncias psicoativas. Rev Ter Ocup Univ São Paulo. 2013 set.dez; 24(3):199-207. Available in: http://www.revistas.usp.br/rto/ article/view/52375/pdf 25 .

4. Wendell AD. Overview and epidemiology sub- stance abuse in pregnancy. Clin Obstet Gynecol 2013; 56:91-6.

5. Rocha Priscila Coimbra, Britto e Alves Maria Teresa Seabra Soares de, Chagas Deysianne Costa das, Silva Antônio Augusto Moura da, Batista Rosangela Fernandes Lucena, Silva Raimundo Antonio da. Prevalência e fatores associados ao uso de drogas ilícitas em gestantes da coorte BRISA. Cad. Saúde Pública [Internet]. 2016 [cited 2016 Aug 23]; 32( 1 ): e00192714. Available from: http://www.scielo.br/scielo.php?script=sci arttext\&pid=S0102-311X2016000100707\&lng=en. Epub Feb 16, 2016. http://dx.doi.org/10.1590/0102-311X00192714.

6. Bertoni N, Burnett C, Cruz MS, Andrade T, Bastos Fl, Leal E, Fischer B. Exploring sex differences in drug use, health and service use characteristics among young urban crack users in Brazil. Int J Equity Health. 2014 Aug; 13(1):70. Available in: http://www.ncbi.nlm.nih.gov/pmc/articles/PMC4243730/

7. Wendt NC, Crepaldi MA. (2008). A utilização do genograma como instrumento de coleta de dados em pesquisa qualitativa. Psicol. Reflex. Crit. 2008; 21(2):302-10. Available in: $\quad$ http://www.scielo.br/scielo.php?script=sci_arttext\&pid $=$ S0102-79722008000200016.

8. Morin EA. Cabeça bem feita: repensar a reforma, reformar o pensamento. Rio de Janeiro: Bertrand Brasil, 2004

9. Biroli F. Família: novos conceitos. São Paulo: Fundação Perseu Abramo, 2014

10. Osório LC, Valle MEP. Manual de terapia familiar. Porto Alegre, RS: Artmed, 2009

11. Schimanski E, Pereira CMS. (2013). Família, gênero e novas configurações familiares: um olhar sobre a mulher e a condição de pobreza. Revista Magistro; 2(8):163-179. Available in: http://publicacoes.unigranrio.edu.br/index.php/magistro/ article/view/2242/1011

12. Bowen M. De la familia ao individuo. Barcelona, España: Paidós, 1991.

13. Yin RK. Case Study Research: Design and Methods. 7. ed. Sage Publications Inc, 2013. 312p. 
14. Minayo MCS. O desafio do conhecimento: pesquisa qualitativa em saúde. 12. ed. São Paulo, SP: Hucitec, 2010.

15. Laboratório de Direitos Humanos, Cidadania e Ética da Universidade Estadual do Ceará-LabVida-UECE, Laboratório de Estudos da Conflitualidade da Universidade Estadual do Ceará-COVIO-UECE \& Laboratório de Estudos da Violência da Universidade Federal do Ceará-LEV-UFC. (2011). Mapa da criminalidade e da violência em Fortaleza. Perfil da SER V. Fortaleza, CE: EdUECE. Available in: http://www.uece.br/covio/ dmdocuments/regional V.pdf.

16. Amazonas MCLA, Damasceno PR, Terto LMS, Silva RR. Arranjos familiares de crianças das camadas populares. Psicol Estud. 2003; 8(spe):11-20. Available in: http://www.scielo.br/pdf/pe/ v8nspe/v8nesa03.pdf.

17. Filizola CLA, Dupas G, Ferreira NMLA, Pavarini SCI. Genograma e Ecomapa: Instrumentos para pesquisa com famílias. In I Conferência Internacional do Brasil de Pesquisa Qualitativa [CD]. Taubaté, SP: Núcleo de Pesquisa da Família, 2004.

18. Caniço H, Bairrada P, Rodríguez E, Carvalho A. Novos tipos de família: plano de cuidados. Coimbra, Portugal: Imprensa da Universidade de Coimbra, 2010.

19. Kurz D. Physical abuse by husbands: A major social problem. In R. Gelles \& D. R. Loseke (Eds.), Current controversies in family violence (pp. 88-103). Newbury Park, CA: Sage, 1993.

20. Madeira MH. Ensino profissional de jovens: um percurso escolar diferente para a (re)construção de projetos de vida. Revista Lusófona de Educação, 2006; 7:121-41. Available in: http:// revistas.ulusofona.pt/index.php/rleducacao/article/view/802.

21. European Commission. Reducing early school leaving: Key messages and policy support Final Report of the Thematic Working Group on Early School Leaving. November 2013. Available in: http://ec.europa.eu/education/policy/strategicframework/doc/esl-group-report en.pdf.

22. Instituto Brasileiro de Geografia e Estatística. (2013). Síntese de Indicadores Sociais: uma análise das condições de vida da população brasileira. Rio de Janeiro, 2013. Available in: http:// biblioteca.ibge.gov.br/visualizacao/livros/liv66777.pdf.

23. Borja IMFS, Martins AMO. Evasão escolar: desigualdade e exclusão social. Revista Liberato. 2014; 15(23):92-4. Available in: http://www.liberato.com.br/sites/default/files/arquivos/Revista SIER/v.\%2015,\%20n.\%2023\%20(2014)/09.\%20Evas\%E30\%20 Escolar.pdf.

24. Aguiar, M. M. "Raça" e Desigualdade: as diversas interpretações sobre o papel da raça na construção da desigualdade social no Brasil. Revista Tempo da Ciência. 2008; 29(15):115-33. Available in: http://files.ufgd.edu.br/arquivos/arquivos/78/NEAB/ AGUIAR-\%20Marcio.\%20Raca\%20e\%20desigualdade.pdf.

25. Perreira KP, Telles EE. The color of health: Skin color, ethnoracial classification, and discrimination in the health of Latin Americans. Social Science \& Medicine. Soc Sci Med. 2014 Sep; 116:241-50. Available in: http://www.sciencedirect.com/science/article/pii/ S0277953614003554
26. Travassos C, Laguardia J, Marques PM, Mota JC, Szwarcwald CL. Comparison between two race/skin color classifications in relation to health-related outcomes in Brazil. Int J Equity Health. 2011; 10:35. Available in: https://equityhealthj.biomedcentral. com/articles/10.1186/1475-9276-10-35.

27. Horta RL, Vieira LS, Balbinot AD, Oliveira GO, Poletto $S$, Teixeira VA. Influência da família no consumo de crack. J Bras Psiquiatr. 2013; 63 (2), 104-12. Available in: http://www.scielo.br/scielo. php? script=sci arttext\&pid=S0047-20852014000200104.

28. Faria CS, Martins CBG. Violence among adolescent students: conditions vulnerability. Enfermería global. 2016; 42:18698. Available in: http://revistas.um.es/eglobal/article/ viewFile/206901/191571.

29. Seleghim MR, Marangoni SR, Marcon SS, Oliveira MLF. Vínculo familiar de usuários de crack atendidos em uma unidade de emergência psiquiátrica. Rev Lat Am Enfermagem. 2011; 19(5):1163-70. Available in: http://www.scielo.br/pdf/rlae/ v19n5/pt 14.pdf.

30. Stone AL, Becker LG, Huber AM, Catalano RF. Review of risk and protective factors of substance use and problem use in emerging adulthood. Addict Behav. 2012 Jul; 37(7):747-75. Available in: http://www.sciencedirect.com/science/article/pii/ S0306460312000810.

31. Alati R, Najman JM, Kinner SA, Mamun AA, Williams GM, O'Callaghan $\mathrm{M}$ et al. Early predictors of adult drinking: $\mathrm{A}$ birth cohort study. Am. J. Epidemiol. 2005; 162(11):1098-1107. Available in: http://aje.oxfordjournals.org/content/162/11/1098.

32. Fidan A, Bui HN. Intimate Partner Violence Against Women in Zimbabwe. Violence Against Women. 2016 Aug; 22(9):10751096. Available in: http://vaw.sagepub.com/content/22/9/1075. short.

33. Lokuge K, Verputten M, Ajakali M, Tolboom B, Joshy G, Thurber KA et al.. Health Services for Gender-Based Violence: Médecins Sans Frontières Experience Caring for Survivors in Urban Papua New Guinea. PLoS One. 2016 Jun; 11(6):1-14, 2016. Available in: http://journals.plos.org/plosone/article?id=10.1371/journal. pone. 0156813

34. Zuma CE, Mendes, CHF, Cavalcanti LF, Gomes R. Violência de gênero na vida adulta.. In Njaine, K., Assis, S. G.\&Constantino, P. (Orgs.). Impactos da Violência na Saúde. 2. ed. Rio de Janeiro, RJ: Fundação Oswaldo Cruz,2009. pp. 149-181.

35. Gomes NP, Diniz NMF, Araújo AJS, Coelho TMF. (2007). Compreendendo a violência doméstica a partir das categorias gênero e geração. Acta Paul Enferm. 2007; 20(4):504-8. Available in: http://www.scielo.br/scielo.php?script=sci_arttext \&pid=S0103-21002007000400020.

36. Ferreira AL, Moura ATMS, Morgado R, Gryner S, Castello Branco VM. Crianças e adolescentes em situação de violência. In Njaine, K., Constantino, P. \& Assis, S. G. (Orgs.). Impactos da Violência na Saúde. 2. ed. Rio de Janeiro, RJ: Fundação Oswaldo Cruz, 2009. pp. 127-148. 
37. Devries KM, Mak JY, García-Moreno C, Patzold M, Child JC, Falder $\mathrm{G}$ et al. The global prevalence of intimate partner violence against women. Science. 2013 Jun; 340: 1527-28. Available in: http://science.sciencemag.org/content/340/6140/1527.long.

38. Stöckl H, Devries K, Rotstein A, Abrahams N, Campbell J, Watts $\mathrm{C}$ et al. The global prevalence of intimate partner homicide: a systematic review. Lancet. 2013 Sept; 382(9895):859-65. Available in: http://www.sciencedirect.com/science/article/pii/ S0140673613610302.

39. Reis HFT, Moreira TO. O crack no contexto familiar: uma abordagem fenomenológica. Texto Contexto Enferm. 2013; 22(4):1115-23. Available in: http://www.scielo.br/scielo. php?script=sci arttext\&pid=S0104-07072013000400030.

40. Alvarez SQ, Gomes GC, Xavier DM. Causes of addiction and its consequences for the user and the family. J Nurs UFPE on line. 2014 mar; 8(3):641-8. Available in: http://www.revista.ufpe.br/ revistaenfermagem/index.php/revista/article/viewArticle/3509.

41. Pinho LB, Oliveira IR, Gonzales RIC, Harter J. Consumo de crack: repercusiones en la estructura y en la dinamica de las relaciones familiares. Enfermería Global. 2012; 11(25):139-49. Available in: http://scielo.isciii.es/pdf/eg/v11n25/pt docencia3.pdf.

Vol. 9 No. 280 doi: $10.3823 / 2151$
Publish in International Archives of Medicine

International Archives of Medicine is an open access journal publishing articles encompassing all aspects of medical science and clinical practice. IAM is considered a megajournal with independent sections on all areas of medicine. IAM is a really international journal with authors and board members from all around the world. The journal is widely indexed and classified Q1 in category Medicine. 